\title{
Burnout Syndrome in Bank Employees: A Literature Review
}

\author{
Felipe Silva Dias* \\ Orcid.org/0000-0003-2706-8657 \\ Antonio Paulo Angélico \\ Orcid.org/0000-0002-6926-0439
}

Universidade Federal de São João del-Rei, São João del-Rei, MG, Brasil

\begin{abstract}
This study aims to identify the empirical studies that investigate the prevalence of and factors associated with burnout syndrome in bank employees that were published in the PUBMED, SciELO, LILACS, MEDLINE, PsycINFO, ISI Web of Knowledge and Science Direct indexers, and to analyze such studies with regard as to the research methods they used. Fourteen studies were identified that were grouped into the socio-demographic, personal, organizational and labor variables related to burnout. The sample size ranged from 50 to 6091 participants (median $=250.5$ ). Two studies investigated prevalence and found that $49.6 \%$ and $55.78 \%$ of the participants were affected by the syndrome. Most studies were surveys, and there was only one experiment. Participants working 40 hours, or more, per week and who had direct contact with customers were seen to be the most affected by the syndrome. Physical exercise helped reduce burnout levels in participants. Critical analysis identified the need for further studies with case and non-case groups of the syndrome, and the inclusion of other personal, organizational and work variables, thus enabling a better understanding of burnout and the development of technologies needed to reverse and prevent it, and in order to support a generalization of the results.
\end{abstract}

Keywords: Burnout syndrome, bank employees, prevalence, associated factors.

\section{Síndrome de Burnout em Trabalhadores do Setor Bancário: Uma Revisão de Literatura}

\section{Resumo}

Objetiva-se identificar, nos indexadores PUBMED, SciELO, LILACS, MEDLINE, PsycINFO, ISI Web of Knowledge e Science Direct, estudos empíricos que investigassem a prevalência e os fatores associados à síndrome de burnout em bancários, e analisá-los em relação aos delineamentos de pesquisa empregados. Foram identificadas 16 pesquisas, agrupadas em variáveis sociodemográficas, pessoais, organizacionais e laborais relacionadas ao burnout. O tamanho da amostra variou de 50 a 6.091 participantes (mediana $=250,5$ ). Duas pesquisas investigaram prevalência, encontrando um resultado de 49,6 e 55,78\% dos participantes acometidos pela síndrome. A maioria dos estudos caracterizou-se como pesquisas de levantamento, sendo apenas um experimental. Observou-se que os participantes com jornadas

* Mailing address: 83 Rua Frei Optato, Tijuco, São João del-Rei, MG, Brazil 36309-312. E-mail: felipsdias@ yahoo.com.br and angelico.fmrp.usp@gmail.com 
de trabalho igual ou superior a 40 horas semanais e contato direto com clientes foram os mais acometidos pela síndrome. A realização de exercícios físicos se mostrou capaz de reduzir os níveis de burnout entre os participantes. A análise crítica apontou a necessidade de novos estudos com grupos caso e não caso da síndrome e inclusão de outras variáveis pessoais, organizacionais e laborais, que permitam uma melhor compreensão do burnout e o desenvolvimento de tecnologias para sua reversão e prevenção, além de respaldar a generalização dos resultados.

Palavras-chave: Síndrome de burnout, bancários, prevalência, fatores associados.

\section{Síndrome de Burnout en Trabajadores del Sector Bancario: Una Revisión Literaria}

\section{Resumen}

Se pretende identificar, en las bases de datos PUBMED, SciELO, LILACS, MEDLINE, PsycINFO, ISI Web of Knowledge e Science Direct, estudios empíricos que investigaron la prevalencia y los factores asociados al síndrome de burnout en trabajadores bancarios y analizarlos en relación a los métodos de investigación utilizados. Se identificaron 16 estudios agrupados en variables sociodemográficas, personales, organizacionales y laborales, relacionadas al burnout. El tamaño de la muestra varió de 50 a 6.091 participantes (mediana $=250,5$ ). Dos investigaciones examinaron la prevalencia, encontrando los resultados de 49,6 y 55,78\% de los participantes afectados por el síndrome, respectivamente. La mayoría de los estudios se caracterizó como investigaciones por encuesta, y solamente una como experimental. Los participantes con jornada de trabajo igual o superior a 40 horas semanales y contacto directo con clientes fueron los más afectados por el síndrome. La realización de actividades físicas se mostró capaz de reducir los niveles de burnout entre los participantes. El análisis crítico apuntó la necesidad de realizar nuevos estudios con grupos caso y control del síndrome, así como la inclusión de otras variables personales, organizacionales y laborales, que permitan una mejor comprensión del burnout y el desarrollo de tecnologías para su reversión y prevención, más allá de respaldar la generalización de los resultados.

Palabras clave: Síndrome de burnout, trabajadores bancarios, prevalencia, factores asociados.

The term burnout to describe the state of exhaustion found in workers was first used in 1974, most authors attributing it to Freudenberger. Other terms were used to describe conditions similar to burnout, such as "overstrain", "neurocirculatory asthenia", "industrial fatigue", and "being burned out" (Benevides-Pereira, 2014). In Brazil, "professional exhaustion syndrome" and a "feeling of being finished" are expressions commonly used as synonyms for burnout syndrome (Ministry of Health, 2001).

The definition of burnout initially most accepted was proposed by Maslach and Jackson (1981), in which it was understood to be a syndrome characterized by emotional exhaustion, depersonalization and low professional achievement, which frequently occurs among individuals who work in close contact with other people. Since this formulation was suggested, emotional exhaustion and depersonalization have been considered to be aspects related to burnout, although independent. The understanding of burnout was subsequently extended from the intense demands of customer service to include other work that requires creativity, problem solving or mentoring (Schaufeli, Leiter, $\&$ Maslach, 2008). So the three initial aspects (dimensions) began to be conceptualized in slightly more comprehensive terms as far as concerns work and not just personal relationships (Maslach, Schaufeli, \& Leiter, 2001).

Within this conception, 'emotional exhaustion' is defined as a lack of energy and enthusiasm and the feeling of resource exhaustion 
(Carlotto \& Câmara, 2004), which may manifest itself in various symptoms, such as headaches, nausea, muscular tension, low back or cervical pain, sleep disturbance, impatience, irritability, etc. (Trigo, Teng, \& Hallak, 2007). 'Depersonalization' refers to the impersonality with which a professional treats the people around them, such as dealing with customers and colleagues as if they were objects, and developing emotional insensitivity (Carlotto \& Câmara, 2004). In occupations that do not involve patient or customer service, this dimension can be characterized by the development of a distant attitude and an indifference towards the work, rather than with the people with whom one is working (Maslach et al., 2001; Schaufeli, 2003). Benevides-Pereira (2007) divided the 'depersonalization' dimension into two others; 'dehumanization' and 'emotional distancing'. 'Low personal achievement' ('low professional achievement' or 'low achievement in work') is a worker's tendency to self-evaluate negatively, and to feel unhappy and dissatisfied with his or her professional development (Carlotto \& Câmara, 2004).

In the explanatory model of burnout suggested by Demerouti, Bakker, Nachreiner and Schaufeli (2001), the origin of the illness occurs in the mismatch that exists between work demands and work resources, being thus described by way of two processes. In the first, the authors argue that typical work demands, especially excess work, can lead to overload and, as a consequence, to emotional exhaustion. The second refers to the lack of resources, which can aggravate the effects of the demands and lead to distancing and cynical behavior. These, in turn, can generate, in the long term, a reduction in engagement with work, or total disengagement.

Benevides-Pereira (2010) stated that burnout is a process triggered by factors of the organizational context, such as work organization, the physical environment and industrial relations. This author believes that personal characteristics are facilitators in this illness, which may have both personal and social consequences. In this case, people who are idealistic, highly motivated, who identify with their work, are empath- ic, have high expectations, are responsible and perfectionists, would be more likely to develop this syndrome under adverse organizational conditions.

Generally speaking, burnout produces negative effects on workers, colleagues, the workplace, customers and the organization. In addition to the symptoms suffered by the worker, burnout also leads to consequences in terms of work, since it has a negative effect on quality and job satisfaction, and interferes with both social and family relationships. Colleagues are also affected, since the quality of relationships tends to reduce and productivity may be lower, thus generating more workload. The reduction in service quality and the financial losses resulting from the provision of poor quality service are impacts of burnout that affect the organization's customers. In turn, there may be a loss in quality in the organization's services, thus reducing the value of its image vis-à-vis the market and its customers. The symptoms may also lead to increased turnover, absenteeism and presenteeism, a condition in which the person is present at work, but their productivity is as low as if they were absent (Trigo et al., 2007).

Because it was initially related to intense contact with other people, a large part of the research was devoted to studying professionals working in care activities, such as health care (Ebling \& Carlotto, 2012; Lorenz \& Guirardello, 2014). Other studies have turned to the occurrence of the syndrome in different working contexts, but in which there is also intense contact with people, such as penitentiary agents, teachers, the police and social services (Carlotto \& Câmara, 2007; Rodríguez-Amaya, 2014; Silveira et al., 2005).

According to the literature review undertaken by Trigo et al. (2007), data on burnout syndrome are still uncertain with regard to its prevalence and comorbidity with psychiatric disorders. The authors stated that little is known about the prevalence of burnout in the general population, but that data point to similar prevalence rates within the professional categories investigated, such as doctors, teachers and nurses. Prevalence 
studies in Brazil have concentrated on health and education professionals. In this review work, research carried out with bank employees, a professional group, the nature of whose activity is typically similar to that of other professional groups with a high prevalence of burnout, was not mentioned.

In the context of banking work in Brazil, exposure to verbal abuse from customers and management and the risk of assault and kidnapping have been associated with stress, anxiety and burnout (Jacques \& Amazarray, 2006). Workplace harassment has been so recurrent that the banks themselves have been creating mechanisms for controlling this harmful practice, such as employing internal ombudsmen and communication teams. The unions have also included such mechanisms in their collective bargaining agreements, demanding instruments from financial institutions for preventing and combatting harassment (Confederação Nacional dos Trabalhadores do Ramo Financeiro [CONTRAF], 2015). It is also necessary to consider the change in the structure of banking activity, which since the 1990s has ceased to be based on bureaucratic tasks and has started requiring that workers meet commercial, profitability and new customer goals, thus creating increasing anxiety and competitiveness among peers (Araujo, Cartoni, \& Justo, 2001; Laranjeira, 1997; Paiva, Damasceno, \& Borges, 2009). Within the demands and work resource model (Demerouti et al., 2001), it is clear that the nature of work in financial institutions is marked by demands that require a constant physical and mental effort. Resources, in their turn, are not always sufficient to reduce the impact of the demands on workers' health.

A significant part of the demands in banking work comes from the typical requirements that are associated with intense contact with people. According to Schaufeli, Maslach and Marek (1993), contact with people is demanding and exhausting, and is one of the root causes of burnout. Although other factors can be included as generators of the syndrome in this group of workers, such as excessive targets and the requirement of high productivity, contact with people should also be considered. Given these characteristics, bank employees can be assessed as being a professional group that is at great risk of developing the syndrome.

Considering the impacts that the burnout syndrome can have on: workers, colleagues, customers and companies; the nature of banking activity; the risk tat workers in this sector run of developing the syndrome; and the inconsistency of the data found in the literature, this review intends to identify articles in the indexed databases that contain reports of empirical research that investigated both the prevalence of the syndrome in bank workers and its relationship with sociodemographic, personal, organizational and work variables, but without establishing time period limits for the searches that were carried out. The aim, therefore, is to characterize and analyze the research critically, especially the methods used and results found.

\section{Procedure}

In order to identify research into burnout in bank workers, systematic searches were carried out in the PUBMED, SciELO, LILACS, MEDLINE, PsycINFO, ISI Web of Knowledge and Science Direct databases, using a combination of the following descriptors: burnout, banking, bank office, overstrain, neurocirculatory asthenia, industrial fatigue, being burned out, professional exhaustion syndrome, a feeling of being finished and bank employees. Quantitative studies, with samples taken from both genders, were included. We considered the following to be exclusion criteria: (a) studies conducted with samples covering different professional groups, in addition to bank workers; and (b) research aimed at validating the measurement instruments.

We found 16 articles with search procedures that met the inclusion and exclusion criteria that were established as the limits of this review work. Among them, we identified that two (AlKahtani \& Allam, 2013, 2014) were single study reports and they were treated as such. So 15 we identified and analyzed 15 studies.

In the analysis carried out, we considered research design, the data collection and analysis procedures, and the sociodemographic, personal, 
organizational and labor variables that were investigated. With regard to research design and procedures, we analyzed: (a) sample size; (b) whether there was an assessment of prevalence; (c) the type of outlining used; (d) the instrument used; (e) the number of variables investigated that had a possible relationship with burnout; (f) the number of dimensions used to assess burnout; and $(\mathrm{g})$ whether the overall burnout score was calculated, or only its dimensions in the process of calculating the instruments used in the studies.

Individual characteristics that may be related to burnout, such as health-related issues, repertoires (like coping strategies), and the family environment in which the workers lived (for example, whether they lived with children, or not) were included as personal variables. The organizational variables have to do with issues related to the organization's structure, policies and practices, such as working hours and length of service. As work variables, we considered those related to the properties of the work itself and to the nature of the activity, such as:

1. The conditions under which it takes place;

2 . The necessary repertoire or patterns of behavior that the task requires (e.g. the need to suppress negative emotions);

3. The products of the activity for the person, customers and the organization; and

4. Interactions with other activities and other life dimensions, such as the time conflict generated between needs arising from work and other life instances (work-life time conflict).

\section{Results}

The research design is set out in Table 1, showing sample size $(N)$, the prevalence found, the type of design used and the instrument used, the number of variables assessed in the research, and the number of dimensions used in assessing burnout and whether the syndrome was assessed using an overall score.

As for the size of the sample, the research we looked at ranged from 50 (Mutsvunguma \& Gwandure, 2011) to 6091 participants $(\mathrm{Br}$ auchli et al., 2011), with a median of 250.5. Of the 14 studies we investigated, only two measured prevalence (Al-Kahtani \& Allam, 2014; Amigo et al., 2014) and we found no research that looked at this epidemiological characteristic. Al-Kahtani and Allam (2014) divided the sample $(N=274)$ into two groups - high burnout and low burnout - and presented prevalence in absolute numbers, 138 individuals with low burnout and 136 with high burnout, but did not inform the classification criterion they used. We can therefore consider that they found a burnout prevalence of $49.6 \%$ in their sample. Amigo et al. (2014) analyzed the risk of burnout in each of the three dimensions investigated (emotional exhaustion, cynicism and efficacy), and divided into three levels (low, medium and high), but they did not inform the criterion they used. The results showed that $63.16 \%$ of the sample had high levels in the emotional exhaustion dimension, $60.92 \%$ had high levels of cynicism (depersonalization) and $28.41 \%$ had low levels of efficacy (professional achievement). Moreover, $77.78 \%$ of the individuals were at high risk in at least one of the three dimensions, $55.78 \%$ in two and $18.94 \%$ in all three dimensions. According to these authors, the most frequent combination of factors was between emotional exhaustion and cynicism, which was observed in $50.48 \%$ of the sample. This statement is consistent with the study carried out by Schaufeli, Bakker, Hoogduin, Schaap and Kladler (2001), which indicated that the emotional exhaustion and depersonalization dimensions were sufficient to distinguish workers that have or do not have burnout and that these dimensions were considered as being at the core of the syndrome. Nevertheless, Amigo et al. (2014) adopted high risk levels in at least two dimensions as a criterion for burnout, indicating a prevalence of $55.78 \%$.

With regard to the type of design used in the research, one was experimental (Tsai et al., 2013), while the others were surveys, one with a longitudinal cut (Houkes et al., 2003) and 12 with cross-sectional cuts. Tsai et al. (2013) compared groups (two groups with different interventions and a control group) by way of pre-test and post-test measures. Houkes et al. (2003) collected information twice in their sample with an interval of one year between collections. 
Table 1

Characterization of the Designs Used, the Number of Variables Investigated and the Dimensions (factors) Used in the Association with Burnout Syndrome

\begin{tabular}{cccllcccccc}
\hline & \multicolumn{3}{c}{ General characteristics } & & \multicolumn{3}{c}{ Variables } & & \multicolumn{3}{c}{$\begin{array}{c}\text { Burnout } \\
\text { assessment }\end{array}$} \\
\hline Stud & \multicolumn{1}{c}{$N$} & Prev & Type & Instrument & Soc & Pers & Org & Work & NF & OS \\
\hline 1 & 627 & - & $\begin{array}{l}\text { Survey } \\
\text { (longitudinal) }\end{array}$ & MBI & - & 3 & 3 & 3 & 1 & No \\
2 & 494 & - & Survey & EES & 1 & 5 & 6 & - & 1 & No \\
3 & 200 & - & Survey & EMEDO & 4 & 10 & 1 & 1 & 3 & No \\
4 & 6091 & - & Survey & C-CBI & 4 & 2 & 1 & 3 & 1 & Yes \\
5 & 264 & - & Survey & MBI & 4 & 1 & 1 & - & 3 & No \\
6 & 237 & - & Survey & MBI & - & 1 & 1 & 4 & 3 & Yes \\
7 & 50 & - & Survey & MBI & - & - & - & 1 & 3 & Yes \\
8 & 217 & - & Survey & MBI - GS & 2 & - & 4 & 2 & 3 & No \\
9 & 89 & - & Experimental & C-CBI & - & 3 & - & - & 2 & No \\
10 & 274 & $49.6 \%$ & Survey & MBI & 1 & - & - & 1 & 1 & Yes \\
11 & 1341 & $55.78 \%$ & Survey & MBI - GS & 1 & - & 1 & - & 3 & No \\
12 & 1239 & - & Survey & MBI - GS & 4 & 2 & 2 & 2 & 3 & No \\
13 & 120 & - & Survey & BM & - & - & 1 & 4 & 1 & No \\
14 & 186 & - & Survey & MBI & - & 2 & - & 2 & 1 & No \\
15 & 543 & - & Survey & MBI & - & - & 3 & - & 2 & No \\
\hline
\end{tabular}

Note. 1: Houkes, Janssen, Jonge, and Bakker (2003); 2: Pinheiro, Trócolli, and Paz (2006); 3: Prado, Saisó, Alpizar, and Cabrera (2008); 4: Brauchli, Bauer, and Hämmig (2011); 5: Cakınberk (2011); 6: Khattak, Khan, Haq, Arif, and Minhas (2011); 7: Mutsvunguma and Gwandure (2011); 8: Tayfur, Karapinar, and Camgoz (2013); 9: Tsai et al. (2013); 10: Al-Kahtani and Allam (2013, 2014); 11: Amigo, Asensio, Menéndez, Redondo, and Ledesma (2014); 12: Li et al. (2015); 13: Sliter, Jex, Wolford, and McInnerney (2015); 14: Ashill, Rod, and Gibbs (2015); 15: Elçi, Karabay, and Akyüz (2015). Stud.: Studies; N: Number of participants; Prev.: Prevalence; Soc.: Sociodemographics; Pers.: Personal; Org.: Organizational; Work: Work; NF: Number of factors; OS: Overall score; - : absent.

As for burnout assessment, the Maslach Burnout Inventory (MBI), or its MBI-GS (General Survey) version, was used in 10 pieces of research, and was the most widely used measurement instrument in the studies selected. One piece of research (Prado et al., 2008) used the Mexican Scale of Occupational Wear (EMEDO), two studies (Brauchli et al., 2011; Tsai et al., 2013) assessed the syndrome using the Copenhagen Burnout Inventory (C-CBI), one (Sliter et al., 2015) used the Burnout Measure (BM) and another (Pinheiro et al., 2006) used the Emotional Exhaustion Scale (EES).

Among the studies we found, there was a variation in the number of dimensions (factors) considered when assessing burnout. Two pieces of research analyzed burnout by means of just an overall score (Al-Kahtani \& Allam, 2013, 2014; Brauchli et al., 2011). Four studies used only the emotional exhaustion scale of the MBI (Ashill et al., 2015; Houkes et al., 2003), BM (Sliter et al., 2015) or EES instruments (Pinheiro et al., 2006). Two other investigations analyzed burnout using two factors, namely: emotional exhaustion and low professional achievement (Tsai et al., 2013), and emotional exhaustion and depersonalization (Elçi et al., 2015). The other studies investigated burnout considering three factors, two of which also assessed the overall score (Khattak et al., 2011; Mutsvunguma \& Gwandure, 2011). 
As far as concerns the variables investigated that were related to the syndrome, sociodemographic variables were included in eight studies (Al-Kahtani \& Allam, 2013, 2014; Amigo et al., 2014; Brauchli et al., 2011, Cakınberk, 2011; Li et al., 2015; Pinheiro et al., 2006; Prado et al., 2008; Tayfur et al., 2013), personal variables in nine (Ashill et al., 2015; Brauchli et al., 2011; Cakınberk, 2011; Houkes et al., 2003; Khattak et al., 2011; Li et al., 2015; Pinheiro et al., 2006; Prado et al., 2008; Tsai et al., 2013), organizational variables in eleven (Amigo et al., 2014; Brauchli et al., 2011; Elçi et al., 2015; Houkes et al., 2003; Li et al., 2015; Pinheiro et al., 2006; Prado et al., 2008; Sliter et al., 2015; Tayfur et al., 2013) and labor variables in ten (Al-Kahtani \& Allam, 2013, 2014; Ashill et al., 2015; Br- auchli et al., 2011; Houkes et al., 2003; Khattak et al., 2011; Li et al., 2015; Mutsvunguma \& Gwandure, 2011; Prado et al., 2008; Sliter et al., 2015; Tayfur et al., 2013).

The types of variable related to the syndrome will be described below. We shall highlight the variables and dimensions in which significant correlations (for correlation studies) or significant differences (for group comparison studies) were found.

\section{Social and Demographic Variables Related to Burnout}

Table 2 shows the research that investigated the relationship between sociodemographic variables and burnout. The results indicate the variables that are significantly related to burnout.

Table 2

Sociodemographic Variables Related to Burnout Syndrome

\begin{tabular}{|c|c|c|c|c|c|}
\hline \multirow{2}{*}{ Studies } & \multicolumn{5}{|c|}{ Variables investigated } \\
\hline & Gender & Age & Marital status & Schooling & Income \\
\hline $\begin{array}{l}\text { Pinheiro et al. } \\
(2006)\end{array}$ & - & $\begin{array}{l}\text { Negative correla- } \\
\text { tion with EE }\end{array}$ & - & - & - \\
\hline $\begin{array}{l}\text { Prado et al. } \\
(2008)\end{array}$ & NS & $\mathrm{NS}$ & & NS & - \\
\hline $\begin{array}{l}\text { Brauchli et al. } \\
\text { (2011) }\end{array}$ & $\begin{array}{l}\text { OS higher } \\
\text { in females }\end{array}$ & NS & NS & $\begin{array}{l}\text { OS higher with less } \\
\text { schooling }\end{array}$ & - \\
\hline $\begin{array}{l}\text { Cakınberk } \\
(2011)\end{array}$ & $\begin{array}{l}\text { Higher levels } \\
\text { of EE } \\
\text { in females }\end{array}$ & $\begin{array}{l}\text { Higher levels } \\
\text { of EE, DP and } \\
\text { lPA in the } 20- \\
30 \text {-year group }\end{array}$ & $\begin{array}{l}\text { Higher levels } \\
\text { of DE and lower } \\
\text { levels of IPA } \\
\text { in single people }\end{array}$ & $\begin{array}{l}\text { Higher levels of EE } \\
\text { and DP and lower } \\
\text { levels of IPA } \\
\text { in graduates than in } \\
\text { those with just a high } \\
\text { school education }\end{array}$ & - \\
\hline $\begin{array}{l}\text { Tayfur et al. } \\
(2013)\end{array}$ & ID & ID & - & - & - \\
\hline $\begin{array}{l}\text { Al-Kahtani } \\
\& \text { Allam } \\
(2013,2014)\end{array}$ & ID & - & - & - & - \\
\hline $\begin{array}{l}\text { Amigo et al. } \\
(2014)\end{array}$ & $\begin{array}{l}\text { Higher levels } \\
\text { of EE and IPA } \\
\text { in females }\end{array}$ & - & - & - & - \\
\hline $\begin{array}{l}\text { Li et al. } \\
(2015)\end{array}$ & - & $\begin{array}{l}\text { Higher levels } \\
\text { of 1PA in the } 30 \\
\text { to } 40 \text { age band }\end{array}$ & ID & $\begin{array}{l}\text { Higher levels of IPA } \\
\text { in the post-graduate } \\
\text { or higher group }\end{array}$ & ID \\
\hline
\end{tabular}

Note. OS: Overall score; EE: Emotional exhaustion; DP: Depersonalization; IPA: low professional achievement; ID: Insignificant difference; - : Variable not investigated. 
The most widely investigated socio-demographic variable was gender (six pieces of research), followed by age group (six studies), marital status (four studies), schooling (four studies) and monthly income band (one study). With regard to gender, Brauchli et al. (2011) found higher levels of burnout in the male group than in the female group, as measured by the overall score. Cakınberk (2011) pointed to higher levels of emotional exhaustion in women than in men $(M=14.14$ and 12.36 , respectively, with $p<.01$ ). Amigo et al. (2014) found greater levels of emotional exhaustion in women $(M=3.72$ and $M=3.43$ for men; $p<.002)$ and lower levels of professional achievement in men $(M=4.34$ and $M=4.47$ for women; $p<.025$ ).

In investigations that compare burnout levels in different age groups, Cakinberk (2011) found greater emotional exhaustion in the 20 to 30 year age group than in the 41 to 50 year age group, and greater depersonalization than in the 31 to 40 year age group. In the professional achievement dimension, the group with ages ranging from 20 to 30 years old had higher levels (indicating a lower burnout index) than those in the 31 to 40 age group, while the 31 to 40 year age group had higher levels than those in the 41 to 50 age group and in the over 50 years old group. On the other hand, Li et al. (2015) found higher levels of professional achievement (lower burnout index) in the group of men aged 30 to 40 years old than in those younger than 30 and over 40 , and in the group of women under 30 than in the 30 to 40 and over 40 years old groups. The studies, therefore, point to inconsistent results, indicating that the relationship between burnout and age band needs to be better investigated. The observed difference can be explained as a function of the culture and social organization where the studies took place.

Cakınberk (2011) found greater depersonalization and less professional achievement in the unmarried group when compared with the married group $(M=7.15$ and $M=5.58, p<.01$, $M=9.29$ and $M=8.10$, respectively, $p<.05$ ). With regard to schooling, Brauchli et al. (2011) reported a negative correlation between the level of schooling (which varied from 1 = "no professional education" to 11 = "university education") and overall burnout scores. Cakınberk (2011) found higher levels of emotional exhaustion and depersonalization and lower levels of professional achievement in graduates when compared with those with a high school education. Li et al. (2015) reported higher levels of professional achievement among the best qualified graduates. These results point to a contradiction regarding the relationship between level of schooling and the professional achievement dimension of burnout, and further studies are needed to understand the interaction between these two variables, seeing that this divergence can also be attributed to the cultural and social differences of each country where the studies were carried out.

\section{Personal Variables Related to Burnout}

Table 3 gives the personal variables related to burnout syndrome, by way of correlation analyses (Pearson or Spearman). Variables were mentioned that were either very positively or very negatively correlated with burnout in the cited studies.

Within the personal variables, the research described a positive correlation between burnout and variables related to health aspects of the participants, such as: sleep, sexual, gastrointestinal, psychoneurotic and pain disorders, and anxiety and depression indicators (Prado et al., 2008); musculoskeletal symptoms in both central and peripheral regions (Pinheiro et al., 2006) and general stress (Brauchli et al., 2011). The research also pointed to a positive correlation between specific repertoires and burnout, such as an over-commitment to work (Li et al., 2015) and negative affectivity (Houkes et al., 2003), which can be defined as a tendency to focus on the negative aspects of oneself, other people and the world in general. Studies also indicated a negative correlation between the syndrome and satisfaction with life (Cakınberk, 2011); personal repertoires involving coping strategies directed at oneself (Ashill et al., 2015), which are understood to be behaviors used to control one's own emotion; and psychological capital 
Table 3

Personal Variables Related to Burnout Using Correlation Tests

\begin{tabular}{|c|c|c|}
\hline Studies & Positive correlations & Negative correlations \\
\hline Pinheiro et al. (2006) & $\begin{array}{l}\text { - Coping by managing symptoms (EE) } \\
\text { - Coping by avoidance (EE) } \\
\cdot \text { Symptoms of the central musculoskeletal regions (EE) } \\
\cdot \text { Symptoms of the peripheral musculoskeletal regions (EE) }\end{array}$ & · Coping control (EE) \\
\hline Prado et al. (2008) & $\begin{array}{l}\cdot \text { Sleep disorders (EE, DP and IPA) } \\
\cdot \text { Sexual disorders (EE, IPA) } \\
\cdot \text { Gastrointestinal disorders (EE, DP and IPA) } \\
\cdot \text { Psychoneurotic disorders (EE, DP and IPA) } \\
\cdot \text { Painful disorders (EE, DP and IPA) } \\
\cdot \text { Anxiety disorder (EE and IPA) } \\
\cdot \text { Depression indicator (EE and IPA) }\end{array}$ & - \\
\hline Brauchli et al. (2011) & - Overall stress (OS) & - \\
\hline Cakınberk (2011) & - & $\begin{array}{l}\text { Satisfaction with life } \\
(\mathrm{EE} \text { and DP) }\end{array}$ \\
\hline Li et al. (2015) & - Over-commitment (EE and DP) & $\begin{array}{l}\text { Psychological } \\
\text { capital (EE, DP and 1PA) }\end{array}$ \\
\hline Ashill et al. (2015) & - & $\begin{array}{l}\text { Coping directed } \\
\text { at oneself }(\mathrm{EE})\end{array}$ \\
\hline Houkes et al. (2003) & $\begin{array}{l}\cdot \text { Negative affectivity }(\mathrm{EE}) \\
\cdot \text { Intrinsic work motivation (EE) }\end{array}$ & - \\
\hline
\end{tabular}

Note. OS: Overall score; EE: Emotional exhaustion; DP: Depersonalization; 1PA: Low professional achievement; - : Absent.

(Li et al., 2015), understood as being a positive psychological state that favors individual performance in the personal growth and development process. In the study by Pinheiro et al. (2006), the 'management' and 'avoidance' coping strategies in relation to musculoskeletal symptoms were positively correlated with emotional exhaustion, while 'control' coping symptoms were correlated negatively with this dimension.

In addition to the results cited, Prado et al. (2008) carried out variance analyses (ANOVA One Way) with the aim of finding out if burnout dimensions were being determined by other variables of interest (painful disorders, psychosexual disorders, gender, marital status, age, and others). An increase in levels of depersonalization was observed when people had used some type of drug once or twice a year, compared with those who had not used any drugs. Brauchli et al. (2011) obtained higher overall scores in the group that did not live with children, when compared with the group that did.

The study by Tsai et al. (2013) was the only one that sought to establish a causal relationship between a treatment variable and the syndrome by way of experimental research. The design used was group comparison, using pre-test and post-test measures. Participants were divided into three groups, the first practiced high intensity exercises, the second, low intensity exercises, and the third was the control group, which did no exercise at all. Using ANOVA, significantly lower levels of burnout were observed in the groups that did both low and high intensity physical activity after the intervention. The reduction observed was significantly different between the three groups, indicating that doing exercise is able to reduce levels of burnout and that high intensity exercises have a greater effect than low intensity exercises. 


\section{Organizational Variables Related} to Burnout

Among the research that was looked at, ten studies evaluated the relationship between burnout and organizational variables using correlation analyses (Pearson or Spearman). The variables that were significantly correlated with burnout are shown in Table 4.

Table 4

Organizational Variables Related to Burnout Using Correlation Tests

\begin{tabular}{|c|c|c|}
\hline Studies & Positive correlations & Negative correlations \\
\hline Pinheiro et al. (2006) & $\cdot$ Overload (EE) & $\begin{array}{l}\text { - Perception of the management style of the bosses } \\
\text { - Material support (EE) } \\
\text { - Pay and development policy (EE) } \\
\text { - Social support (EE) } \\
\text { - Organizational management (EE) }\end{array}$ \\
\hline Tayfur et al. (2013) & $\begin{array}{l}\text { - Turnover intention } \\
\text { (EE, DP and IPA) }\end{array}$ & $\begin{array}{l}\text { - Perception of procedural justice (EE, DP and IPA) } \\
\text { - Perception of distributive justice (EE, DP and IPA) }\end{array}$ \\
\hline Brauchli et al. (2011) & Working day (OS) & - \\
\hline Cakınberk (2011) & $\begin{array}{l}\text { - Length of employment } \\
\text { (EE and IPA) }\end{array}$ & - \\
\hline Khattak et al. (2011) & $\begin{array}{l}\text { Organizational stressors } \\
\text { (EE, DP and IPA) }\end{array}$ & - \\
\hline Sliter et al. (2015) & - & - Quality of customer service \\
\hline Elçi et al. (2015) & - & $\begin{array}{l}\text { - Perception of procedural justice (EE and DP) } \\
\text { - Perception of distributive justice (EE and DP) } \\
\text { - Ethical climate (EE and DP) }\end{array}$ \\
\hline Houkes et al. (2003) & - & - Turnover intention (EE) \\
\hline
\end{tabular}

Note. OS: Overall score; EE: Emotional exhaustion; DP: Depersonalization; 1PA: Low professional achievement - : Absent.

The research found positive correlations between the syndrome and the workday (Brauchli et al., 2011), length of service (Cakınberk, 2011) and organizational stressors (Khattak et al., 2011). With regard to turnover intention, the research pointed to contradictory results, as reported below. Tayfur et al. (2013) obtained a positive correlation between burnout and turnover intention, while Houkes et al. (2003), using a longitudinal study method, found a negative correlation in the first data collection exercise they carried out, but the correlation in the second collection exercise was not significant. The studies also pointed to the negative correlation of the syndrome with the perception of distributive justice, understood as being the perception of justice in the organization's distribution of rewards or punishment, and with procedural justice, understood as the criterion and process used to make this distribution (Elçi et al., 2015; Tayfur et al., 2013). Although both research studies found the same result, a question that needs to be answered is whether a negative perception of distributive and procedural justice may predispose the worker to development of the syndrome, or whether this is what changes their perception of justice. In the study by Elçi et al. (2015), a negative correlation was found between ethical climate and emotional exhaustion and depersonalization.

Another organizational characteristic that was negatively correlated with burnout was the quality of customer service (Sliter et al., 2015). This fact indicates that typical behaviors of the syndrome, especially those related to depersonalization, can have negative consequences for 
the organization, since one of the results of burnout is a reduction in the quality and volume of work produced (Maslach \& Leiter, 1997).

The study by Pinheiro et al. (2006) found significant, negative correlations between emotional exhaustion and the perception of the managerial style of the bosses, material support, the social support of the group, organizational management and the pay and development policy. This dimension of the syndrome was positively correlated with overload in the same research.

With regard to the organizational variables that were related to burnout in a comparison between groups, two studies found significant differences. Li et al. (2015) found higher levels of emotional exhaustion (using the chi-squared test) in the group that worked 40 hours a week or more than in the group that had a working day of less than 40 hours a week $(p<.01)$. Amigo et al. (2014) reported higher levels of emotional exhaustion and depersonalization and lower

\section{Table 5}

Work Variables Related to Burnout Using Correlation Tests

\begin{tabular}{|c|c|c|}
\hline Studies & Positive correlations & Negative correlations \\
\hline $\begin{array}{l}\text { Brauchli et al. } \\
\text { (2011) }\end{array}$ & $\begin{array}{l}\cdot \text { Autonomy in work (OS) } \\
\cdot \text { Work-life time conflict (OS) } \\
\cdot \text { Life-work time conflict (OS) }\end{array}$ & - \\
\hline $\begin{array}{l}\text { Khattak et al. } \\
\text { (2011) }\end{array}$ & $\begin{array}{l}\cdot \text { Activity stressors (EE, DP and IPA) } \\
\cdot \text { Relationship stressors in work (EE, DP and IPA) } \\
\cdot \text { Work environment stressors (EE, DP and IPA) } \\
\cdot \text { Stress associated with the family/work interface (EE, DP and IPA) } \\
\cdot \text { Total stress (OS, EE, DP and IPA) }\end{array}$ & - \\
\hline Li et al. (2015) & $\cdot$ Extrinsic effort (EE and DP) & $\begin{array}{l}\cdot \text { Activity rewards } \\
\text { (EE, DP and IPA) }\end{array}$ \\
\hline Sliter et al. (2015) & $\begin{array}{l}\cdot \text { Customer rudeness }(\mathrm{EE}) \\
\cdot \text { Suppressing negative emotions }(\mathrm{EE}) \\
\cdot \text { Feigning positive emotions (EE) } \\
\cdot \text { Emotional work (EE) }\end{array}$ & - \\
\hline Ashill et al. (2015) & - Stressors at work (EE) & $\begin{array}{l}\text { Social support } \\
\text { at work (EE) }\end{array}$ \\
\hline $\begin{array}{l}\text { Houkes et al. } \\
(2003)\end{array}$ & · Workload (EE) & $\begin{array}{l}\text { Motivating potential } \\
\text { of the task (EE) }\end{array}$ \\
\hline
\end{tabular}

levels of professional achievement in the group that worked in bank branches when compared to the group that worked in support services, which involved internal activities and not working in direct contact with customers $(p<.01)$. The data from the study by Amigo et al. (2014) strengthen the statement that the origin of the syndrome may lie in the contact with people, which is demanding and exhausting in itself (Schaufeli et al., 1993), because in bank branch work there is a much greater and more intense contact with people (customers) than in operational support services.

\section{Work Variables Related to Burnout}

Studies that evaluated the relationship between burnout and labor variables found significant correlations between the syndrome and characteristics of the environment in which work takes place, the repertoires demanded by the activity, the characteristics of the activity and the consequences of the task. These variables are presented in Table 5. 
With regard to the environment, Khattak et al. (2011) reported a positive correlation between the syndrome and the presence of stressors in the workplace. Sliter et al. (2015) pointed to the positive correlation between the level of customer rudeness, as perceived by the employee, and emotional exhaustion. The authors also found a positive correlation between this dimension and three of repertoire groups that are required in the activity: the need to suppress negative emotions; the need to feign positive emotions; and emotional work, understood as the need to modulate and manage emotions in the workplace in order to manifest them in accordance with what is expected.

Among the authors who investigated the relationship of the syndrome with characteristics of the activity, Brauchli et al. (2011) reported positive correlations between the syndrome and three aspects of work:

1. Autonomy in work;

2. The work-life time conflict, understood as the need to stop doing something in life's domains in general because of work-related time demands; and

3. The life-work time conflict, the need to stop doing something at work because of a demand from other life domains. A similar result was found by Khattak et al. (2011), in which burnout was positively correlated with stress arising from the interface between family and work, which is the inability to manage the interface between demands that originate from both work and family. The same authors also found a positive correlation between burnout and activity stressors, work relationship stressors and total stress. Studies reported a positive correlation between the emotional exhaustion dimension and stressors at work (Ashill et al., 2015) and the perceived workload (Houkes et al., 2003).

On the other hand, the research found negative correlations between burnout and the rewards perceived by employees ( $\mathrm{Li}$ et al., 2015); social support at work (Ashill et al., 2015); and the motivating potential of the task, understood as autonomy, feedback, skills variety, identification and the significance of the task (Houkes et al., 2003). The data cited above strengthen the contentions of Schaufeli et al. (2008), who point to two distinct experiences associated with burnout: the imbalance between demand and resources and the mismatch between company and worker values.

With regard to the research that found a relationship between labor variables and burnout by comparing groups (Student t-test), two studies found significant differences. The study by Mutsvunguma and Gwandure (2011) reported higher levels of burnout in the group that handled cash (physical money) than in the group that handled no money. Al-Kahtani and Allam (2014) found a higher degree of job satisfaction in the group with no criteria for burnout than in the group that met the criteria for the syndrome.

In order to identify which variables were predictors of burnout syndrome, Khattak et al. (2011) performed a multiple regression analysis. The results indicated that the development or occurrence of burnout was attributable to organizational stress (19.3\%), the work environment (20.1\%), stressors originating from relationships $(25.3 \%)$, stressors resulting from the family / work interface $(27.3 \%)$ and activity stressors $(37.8 \%)$. These data, therefore, indicate a greater influence from the characteristics of the activity itself (work factors) on the occurrence of the syndrome.

\section{Final Considerations}

As set out above, generally speaking the research indicated an association between burnout and sociodemographic, personal, organizational and work characteristics. These characteristics can act both as the origin of the syndrome and as modulating agents, or as the consequence of burnout. However, since most studies are characterized as being surveys, the analyses undertaken were predominantly correlational, which makes it difficult to identify the direction of the interference of these variables. In disorders that 
are correlated with the syndrome, for example, it is not possible to evaluate if they act as the origin of the syndrome, if it is burnout that makes people susceptible to the development of disorders, or if the two are caused by a third factor.

With regard to organizational characteristics, the data also did not allow us to identify the agents that boost the risk of burnout in a particular organizational context. One of the problems found is that most of the data were collected by way of self-reports and, therefore, the variables describe the workers' perception of aspects of the organizations rather than the objective characteristics of the organizations. So the data do not allow for the construction of more assertive organizational development strategies.

The results of the research that investigated the relationship between burnout and work variables indicate that it is important to undertake a more in-depth study of the impact of the characteristics of the task on the development of the syndrome. Direct observation, together with interviews being used as data collection instruments, for example, can make for greater objectivity in the investigation into work variables. This type of investigation is important for allowing those characteristics of the activity that really act as the origin or modulator of the syndrome to be identified, thus enabling the environment, type of activity, and repertoire required for the task to be adapted, and the outcomes of the task (for example, compensation, social recognition, etc.) that directly concern the worker to be identified. Another example is that by way of experimental research, an assessment can be made of whether a performancebased compensation system alters the risk of developing burnout.

Although the amount of research dedicated to burnout syndrome has increased, there is still a shortage of studies that investigate it in workers in the banking sector in an international context. Regarding prevalence, the data are even more scarce, indicating the need for further studies in the area.

In Brazil especially, we found a lack of research on burnout in bank employees, indicat- ing the need for further studies in this population, since only one investigation conducted in the country was identified (Pinheiro et al., 2006). Moreover, there are specificities of the profession in Brazil that also need to be investigated. It is important to check the difference between public and private banks, since in both systems there are elements that essentially differentiate the organizations and the structure of work. The job stability found in state-owned banks, for example, may interfere with the occurrence and intensity of burnout. There are also variables that were related to other psychiatric disorders in bank employees in Brazil, whose relationship with burnout can also be investigated, such as bullying (Soares \& Villela, 2012) and goal intensity (Petarli, Salaroli, Bissoli, \& Zandonade, 2015; Silva \& Navarro, 2012).

As there are still few data on the relationship between burnout and sociodemographic, personal, organizational and work variables, the research needs to be broadened to include this type of investigation. It is also important to conduct research that can more accurately identify the influence of these variables on the origin, development, protection from and reversal of burnout. The lack of experimental research on burnout in bank employees is a shortcoming that needs to be overcome, even in the international context. The broadening of both survey-type and experimental research can be used as back-up for a generalization of the results.

\section{References}

Al-Kahtani, N. S., \& Allam, Z. (2013). A comparative study of job burnout, job involvement, locus of control and job satisfaction among banking employees of Kingdom of Saudi Arabia. Life Science Journal, 10(4), 2135-2144. doi:10.7537/j. issn.1097-8135

Al-Kahtani, N. S., \& Allam, Z. (2014). The influence of job burnout, involvement and locus of control on job satisfaction: Some explorations from banking sector in Saudi Arabia. New York Science Journal, 7(2), 93-101. Retrieved from http://www.sciencepub.net/newyork/ ny0702/013 23265ny070214 93 101.pdf 
Amigo, I., Asensio, E., Menéndez, I., Redondo, S., \& Ledesma, J. A. (2014). Working in direct contact with the public as a predictor of burnout in the banking sector. Psicothema, 26(2), 222-226. doi: $10.7334 /$ psicothema2013.282

Araujo, A. M. C., Cartoni, D. M., \& Justo, C. R. M. (2001). Reestruturação produtiva e negociação coletiva nos anos 90. Revista Brasileira de Ciências Sociais (São Paulo), 16(45), 85112. doi:http://dx.doi.org/10.1590/S010269092001000100005

Ashill, N., Rod, M., \& Gibbs, T. (2015). Coping with stress: A study of retail banking service workers in Russia. Journal of Retailing and Consumer Services, 23(1), 58-69. doi:10.1016/j.jretconser.2014.12.006

Benevides-Pereira, A. M. T. (2007) Análise do ISB Inventário da Síndrome de Burnout. Retrieved from http:/gepeb.wordpress.com/isb/

Benevides-Pereira, A. M. T. (2010). Burnout: Uma tão conhecida desconhecida síndrome. In G. C. T. M. Levy \& F. P. Nunes Sobrinho (Eds.), A sindrome de burnout em professores do ensino regular: Pesquisa, reflexões e enfrentamento (pp. 9-28). Rio de Janeiro, RJ: Cognitiva.

Benevides-Pereira, A. M. (2014). Burnout: O processo de adoecimento pelo trabalho. In A. M. Benevides-Pereira (Ed.), Burnout: Quando o trabalho ameaça o bem-estar do trabalhador ( $4^{\text {th }}$ ed.). São Paulo, SP: Casa do Psicólogo.

Brauchli, R., Bauer, G. F., \& Hämmig, O. (2011) Relationship between time-based work-life conflict and burnout. Swiss Journal of Psychology, 70(3), 165-174. doi:10.1024/1421-0185/a000052

Cakınberk, A. (2011). Studying the relationship between employees'occupational burnout levels and satisfaction of life: A research in private banks. African Journal of Business Management, 5(16), 6825-6838. doi:10.5897/AJBM10.1554

Carlotto, M. S., \& Câmara, S. G. (2004). Análise fatorial do Maslach Burnout Inventory (MBI) em uma amostra de professores de instituições particulares. Psicologia em Estudo, 9(3), 499-505. doi:10.1590/S1413-73722004000300018

Carlotto, M. S., \& Câmara, S. G. (2007). Preditores da síndrome de burnout em professores. Psicologia Escolar e Educacional, 11(1), 101-110. doi:10.1590/S1413-85572007000100010
Confederação Nacional dos Trabalhadores do Ramo Financeiro. (2015). Convenção Coletiva de Trabalho 2015/2016. São Paulo, SP: Author. Retrieved from http://www.contrafcut.org.br/conv encoes/1527a14eddef77b8de98a2ed64461986/ download

Demerouti, E., Bakker, A. B., Nachreiner, F., \& Schaufeli, W. B. (2001). The job demans-resources model of burnout. Journal of Applied Psychology, 86(3), 499-512. doi:10.1037/00219010863499

Ebling, M., \& Carlotto, M. S. (2012). Burnout syndrome and associated factors among health professionals of a public hospital. Trends in Psychiatry and Psychotherapy, 34(2), 93-100. doi:10.1590/S2237-60892012000200008

Elçi, M., Karabay, M., \& Akyüz, B. (2015). Investigating the mediating effect of ethical climate on organizational justice and burnout: A study on financial sector. Procedia - Social and Behavioral Sciences, 207(1), 587-597. doi:10.1016/j.sbspro.2015.10.130

Houkes, I., Janssen, P. P. M., Jonge, J., \& Bakker, A. (2003). Personality, work characteristics, and employee well-being: A longitudinal analysis of additive and moderating effects. Journal of Occupational Health Psychology, 8(1), 20-38. doi:10.1037/1076-8998.8.1.20

Jacques, M. G., \& Amazarray, M. R. (2006). Trabalho bancário e saúde mental no paradigma da excelência. Boletim da Saúde (Porto Alegre), 20(1), 93-105.

Khattak, J. K., Khan, M. A., Haq, A. U., Arif, M., \& Minhas, A. A. (2011). Occupational stress and burnout in Pakistan's bankingsector. African Journal of Business Management, 5(3), 810817. doi:10.5897/AJBM10.395

Laranjeira, S. M. (1997). Reestruturação produtiva no setor bancário: A realidade dos anos 90. Educação. Social, Campinas, 18(61), 110138. doi:http://dx.doi.org/10.1590/S010173301997000400006

Li, X., Kan, D., Liu, L, Shi, M., Wang, Y., Yang, X., ...Wu, H. (2015). The mediating role of psychological capital on the association between occupational stress and job burnout among bank employees in China. International Journal of Environmental Research and Public Health, 12(1), 2984-3001. doi:10.3390/ijerph120302984 
Lorenz, V. R., \& Guirardello, E. B. (2014). The environment of professional practice and burnout in nurses in primary healthcare. Revista LatinoAmericana de Enfermagem, 22(6), 926-933. doi:10.1590/0104-1169.0011.2497

Maslach, C., \& Jackson, S.E.(1981). The measurement of experienced burnout. Journal of Occupational Behaviour, 2(2), 99-113. Retrieved from http:// www.jstor.org/stable/3000281

Maslach, C., \& Leiter, M. P. (1997). Trabalho: Fonte de prazer ou desgaste. Campinas, SP: Papirus.

Maslach, C., Schaufeli, W. B., \& Leiter, M. P. (2001). Job Burnout. Anual Review of Psychology, 52, $397-422$

Ministry of Health. (2001). Doenças relacionadas ao trabalho: Manual de procedimentos para os serviços de saúde. Brasília, DF: Author.

Mutsvunguma, P., \& Gwandure, C. (2011). The psychological well-being of employees who handle cash in a bank in inner city Johannesburg. Psychology, Health \& Medicine, 16(4), 430436. doi:10.1080/13548506.2011.555771

Paiva, C. S., Damasceno, L., \& Borges, L. O. (2009). O ambiente de trabalho no setor bancário e o bem-estar. Psicologia e Estudo, 14(1), 57-66. doi:http://dx.doi.org/10.1590/S141373722009000100008

Petarli, G. B., Salaroli, L. B., Bissoli, N. S., \& Zandonade, E. (2015). Autoavaliação do estado de saúde e fatores associados: Um estudo em trabalhadores bancários. Cadernos de Saúde Pública, 31(4), 787-799. doi:https://dx.doi. org/10.1590/0102-311X00083114

Pinheiro, F. A., Tróccoli, B. T., \& Paz, M. G. T. (2006). Preditores psicossociais de sintomas osteomusculares: A importância das relações de mediação e moderação. Psicologia: Reflexão \& Crítica, 19(1), 142-150. doi:http://dx.doi. org/10.1590/S0102-79722006000100019

Prado, J. F., Saisó, A. G., Alpizar, C. N., \& Cabrera, A. G. (2008). Perfil psicosomático y de desgaste ocupacional en cajeros del sector bancario con Escala EMEDO. Ciencia \& Trabajo, 10(30), 143-150. Retrieved from http://www.cienciaytrabajo.cl/pdfs/30/pagina143.pdf

Rodríguez-Amaya, R. M. (2014). Síndrome de burnout en guardianes penitenciarios, Bucaramanga, Colombia, 2013. Revista Colombiana de Psiquiatría, 43(3), 146-153. doi:10.10167j. rcp.2014.03.001

Schaufeli, W. B. (2003). Past performance and future perspectives of burnout research. SA Journal of Industrial Psychology, 29(4), 1-15. doi:10.4102/ sajip.v29i4.127

Schaufeli, W. B., Bakker, A. B. Hoogduin, K., Schaap, C., \& Kladler, A. (2001). On the clinical validity of the Maslach Burnout Inventory and Burnout Measure. Psychology and Health, 16(5), 565-582.

Schaufeli, W. B., Leiter, M. P., \& Maslach, C. (2008). Burnout: 35 years of research and practice. Career Development International, 14(3), 204220.

Schaufeli, W. B., Maslach, C., \& Marek, T. (1993). The future of burnout. In W. B. Schaufeli, C. Maslach, \& T. Marek (Eds.), Professional burnout: Recent developments in theory and research (pp. 253-259). New York: Taylor \& Francis.

Silva, J. L., \& Navarro, V. L. (2012). Organização do trabalho e saúde de trabalhadores bancários. Revista Latino-Americana de Enfermagem, 20(2), 226-234. Retrieved from http://www.scielo. $\mathrm{br} /$ scielo.php? script $=$ sci_arttext\&pid $=\mathrm{S} 0104$ $11692012000200003 \& \operatorname{lng}=$ en\&tlng $=$ pt

Silveira, N. M., Vasconcellos, S. J. L., Cruz, L. P., Kiles, R. F., Silva, T. P., Castilhos, D. G., \& Gauer, G. J. C. (2005). Avaliação de burnout em uma amostra de policiais civis. Revista de Psiquiatria do Rio Grande do Sul, 27(2), 159163. doi:10.1590/S0101-81082005000200006

Sliter, M., Jex, S., Wolford, K., \& McInnerney, J. (2010). How rude! Emotional labor as a mediator between customer incivility and employee outcomes. Journal of Occupational Health Psychology, 15(4), 468-481. doi:10.1037/ a0020723

Soares, L. R., \& Villela, W. V. (2012). O assédio moral na perspectiva de bancários. Revista Brasileira de Saúde Ocupacional, 37(126), 203-212. Retrieved from http://www.scielo. br/scielo.php?script $=$ sci_arttext\&pid $=$ S0303$76572012000200003 \& \operatorname{lng}=$ en\&tlng=pt

Tayfur, O., Karapinar, P. B., \& Camgoz, S. M. (2013). The mediating effects of emotional exhaustion cynicism and learned helplessness on organizational justice-turnover intentions linkage. Inter- 
national Journal of Stress Management, 20(3), 193-221. doi:10.1037/a0033938

Trigo, R. T, Teng, C. T., \& Hallak, J. E. C. (2007). Síndrome de burnout ou estafa profissional e os transtornos psiquiátricos. Revista de Psiquiatria Clínica, 34(5), 223-233. Retrieved from http:// www.hcnet.usp.br/ipq/revista/vol34/n5/pdf/223. pdf

Tsai, H. H., Yeh, C. Y., Su, C. T., Chen, C. J., Penq, S. M., \& Chen, R. Y. (2013). The effects of exercise program on burnout and metabolic syndrome components in banking and insurance workers. Industrial Health. 51(3), 336-346. Retrieved from http://www.ncbi.nlm.nih.gov/ pubmed/23518604

(C) The Author(s), 2018. Open Access. This article is distributed under the terms of the Creative Commons Attribution 4.0 International License (http://creativecommons.org/licenses/by/4.0/), which permits unrestricted use, distribution, and reproduction in any medium, provided you give appropriate credit to the original author(s) and the source, provide a link to the Creative Commons license, and indicate if changes were made. 